\title{
DEXAMETHASONE DECREASES MIGRAINE RECURRENCE OBSERVED AFTER TREATMENT WITH A TRIPTAN COMBINED WITH A NONSTEROIDAL ANTI-INFLAMMATORY DRUG
}

\author{
Abouch V. Krymchantowski, Jackeline Soraya Barbosa
}

\begin{abstract}
Background and objectives: Triptans are effective drugs for the acute treatment of migraine. However, $30-40 \%$ of the patients commonly present recurrence before 24 hours therefore requiring another dose. Nonsteroidal anti-inflammatory drugs (NSAID) such as tolfenamic acid and naproxen sodium combined with sumatriptan have demonstrated efficacy in reducing recurrence observed with the single use of this drug. Steroids also have been suggested to treat refractory migraine and status migranosus. The aim of this study was to evaluate whether patients presenting frequent recurrence with the combination triptan plus NSAID, would decrease it with the association of dexamethasone. Method: Twenty three patients, 17 women and 6 men with migraine according to IHS criteria were prospectively studied. All patients presented frequent recurrence $(\geq 60 \%$, mean recurrence rate $74,8 \%)$ with the single use of sumatritpan $100 \mathrm{mg}$ or zolmitriptan $2,5 \mathrm{mg}$ or rizatriptan $10 \mathrm{mg}$ in at least 5 consecutive attacks, and didn't present a reduction of the recurrence rate superior than $20 \%$ with the combination of tolfenamic acid $200 \mathrm{mg}$ or rofecoxib $25 \mathrm{mg}$ in at least 5 other consecutive attacks (mean recurrence rate $60 \%$ ). The patients had to treat 6 consecutive moderate or severe migraine attacks with their usual combination plus $4 \mathrm{mg}$ of dexamathasone with a maximum of twice a week, and fill out a diary reporting headache parameters. Results: Twenty patients, 16 women and 4 men completed the study. Of those who completed the study, 11 took rizatriptan plus rofecoxib, 4 rizatriptan plus tolfenamic acid, 3 zolmitriptan plus rofecoxib, 1 zolmitriptan plus tolfenamic acid and 1 patient took sumatriptan plus tolfenamic acid, having the 20 patients taken as a third medication, a single tablet of $4 \mathrm{mg}$ of dexamethasone. All patients took oral formulations and none presented vomiting after that. Among all 20 patients, one female and one male patient presented recurrence in 3 out of the 6 attacks $(50 \%)$ while the remaining 18 patients revealed recurrence in 1 or 2 treated attacks (mean $23,4 \%)(p<0,001)$. Conclusion: We concluded that the judicious use of oral dexamethasone might be useful for a limited population of migraine patients still presenting recurrence with the combination of a triptan and a NSAID. Case-control studies and studies with a randomized double-blind design are necessary to confirm these observations.
\end{abstract}

KEY WORDS: migraine recurrence, dexamethasone, triptans, nonsteroidal anti-inflammatory drugs.

Dexametasona diminui a recorrência de migrânea observada após tratamento com um triptano e um antinflamatório não esteroide

RESUMO - Tema e objetivos: Triptanos são drogas eficientes para o tratamento agudo da migrânea. Entretanto, cerca de 30 a $40 \%$ dos pacientes tratados, comumente apresentam recorrência antes de 24 horas e consequentemente necessitam de uma nova dose. A associação de antinflamatórios não esteroides (AINE) como o ácido tolfenâmico e o naproxeno sódico demonstraram eficácia na redução da recorrência observada com o uso isolado do sumatriptan. Esteróides também têm sido indicados para o tratamento da migrânea refratária e para o status migranosus. 0 objetivo desse estudo foi avaliar se pacientes que apresentam recorrência frequente mesmo com a combinação de um triptano e um AINE, poderiam diminuir a recorrência com a adição de dexametasona. Método: Vinte e três pacientes, 17 mulheres e 6 homens, com o diagnóstico de migrânea de acordo com os critérios da IHS (Sociedade Internacional de Cefaléia) foram estudados prospectivamente. Todos apresentaram recorrência frequente $(\geq 60 \%$, média de recorrência $74,8 \%)$ com o uso isolado de sumatriptan $100 \mathrm{mg}$ ou zolmitriptan $2,5 \mathrm{mg}$ ou rizatriptan $10 \mathrm{mg}$ em pelo menos 5 crises consecutivas, e não revelaram redução da recorrência superior a $20 \%$ com a adição de ácido tolfenâmico $200 \mathrm{mg}$ ou rofecoxib $25 \mathrm{mg}$ em pelo menos 5 outras crises consecutivas (média de recorrência $60 \%$ ). Os pacientes deveriam tratar 6 crises consecutivas de intensidade moderada ou intensa com a sua medicação habitual mais $4 \mathrm{mg}$ Vo de dexametasona ingerida simultaneamente, não mais de duas vezes por semana, e preencher um relatório

Headache Center of Rio and Institute of Neurology Deolindo Couto/UFRJ, Rio de Janeiro RJ, Brasil.

Received 19 April 2001, received in final form 18 June 2001. Accepted 21 June 2001.

Dr. Abouch Valenty Krymchantowski - Av. Das Américas 1155/1608 - 22631-000 Rio de Janeiro RJ - Brasil. FAX: 214913657.

E-mail: abouchkrym@globo.com -Website: www.dordecabeca.com.br or www.cefaleia.com 


\begin{abstract}
diário com as características da dor. Resultados: Vinte pacientes, 16 mulheres e 4 homens, completaram o estudo. Entre os pacientes que completaram o estudo, 11 usaram rizatriptan + rofecoxib, 4 rizatriptan + ácido tolfenâmico, 3 pacientes zolmitriptan + rofecoxib, 1 zolmitriptan + ácido tolfenâmico e 1 paciente utilizou sumatriptan + ácido tolfenâmico. Todos os pacientes tomaram, como terceira droga, um comprimido de $4 \mathrm{mg}$ de dexametasona. Todos utilizaram formulações orais não tendo sido relatado vômitos após esse uso. Entre os 20 pacientes, uma paciente e um paciente apresentaram recorrência em 3 de 6 crises tratadas (50\%) enquanto entre os 18 remanescentes houve recorrência em 1 ou 2 crises tratadas (média de recorrência $23,4 \%)(p<0,001)$. Conclusão: Concluímos que pacientes com migrânea recorrente, mesmo em uso da combinação de um triptano e um AINE, podem se beneficiar com o uso criterioso de dexametasona oral. Estudos com delineamento do tipo caso-controle ou randomizados e duplo-cegos são necessários para confirmar estas observações.
\end{abstract}

PALAVRAS-CHAVE: recorrência da migrânea, dexametasona, triptanos, antinflamatórios não esteroidais.

Triptans are serotonergic agonists of the receptors $5 \mathrm{HT}_{1 \mathrm{~B} / 1 \mathrm{D}}$ proven effective in the acute treatment of migraine ${ }^{1-3}$. Therefore, the recurrence of the headache and associated symptoms may occur in 25 to $78 \%$ of the patients at least occasionally, and may represent a limitation to the use of this class of substances along with high cost, possible lack of efficacy and side effects ${ }^{4-6}$. Up to $70 \%$ of the patients taking triptans even present with multiple recurrence $^{5}$. Non steroidal anti-inflammatory drugs (NSAID) such as ibuprofen, naproxen sodium and tolfenamic acid are also effective to treat migraine attacks ${ }^{7}$ and the combination of sumatriptan and a NSAID has been demonstrated to reduce the recurrence rate presented by the single use of sumatriptan ${ }^{8,9}$. However, the clinical experience demonstrates that some patients do continue to present with recurrence after successful treatment of their attacks, even with the combination of a triptan and a NSAID. In the other hand, steroids such as dexamethasone and prednisone have been suggested to treat refractory migraine, status migranosus and to terminate the nonresponsive headache cycle observed in rebound ${ }^{10-13}$.

The aim of this study was to evaluate whether a group of patients presenting with frequent recurrence, despite of using the combination triptan-NSAID, would decrease their rate of recurrence with the association of $4 \mathrm{mg}$ PO of dexamethasone to their usual effective drug regimen for the acute treatment of migraine.

\section{METHOD}

Twenty three patients from a private headache center, 17 women and 6 men, ages 29 to 52 years (mean 43), with migraine according to IHS criteria ${ }^{14}$ were prospectively studied. The inclusion criteria were: 1 ) having presented frequent recurrence $(\geq 60 \%$, mean recurrence rate $74,8 \%$ ), which was defined as the returning of the headache after 2 and before 24 hours, once the intensity of the pain firstly decreased from severe or moderate to mild or none, with the single use of sumatritpan $100 \mathrm{mg}$ or zolmitriptan $2,5 \mathrm{mg}$ or rizatriptan $10 \mathrm{mg}$ in at least 5 consecutive attacks, and 2) lack of reduction of the recurrence rate superior than $20 \%$ with the combination of tolfenamic acid $200 \mathrm{mg}$ or rofecoxib $25 \mathrm{mg}$, in at least 5 other consecutive attacks (mean recurrence rate with the combination triptan plus NSAID $=60 \%$ ). The enrolled patients had to treat 6 consecutive moderate or severe migraine attacks with the combination of their usual triptan-NSAID regimen plus $4 \mathrm{mg}$ of dexamathasone, taken simultaneously, with a maximum of twice a week. They also had to fill out a diary reporting headache frequency, intensity, duration, use of acute treatments, presence of vomiting after drug intake and side effects. The author was very rigorous to make sure that all patients received clear and objective information about the side effects and limitations of the steroid use. All patients were using preventive medications other than NSAID, gave their consent to take part in the study and none of them had concomitant medical conditions or were under other types of medication. Patients with history of peptic diseases as well as with any other co-morbidities were not included in the study. The statistical analysis was performed using the Tstudent test with a two-tailed $P$ value $\leq 0.05$ considered significant.

\section{RESULTS}

Twenty patients, 16 women and 4 men completed the study. Two men didn't fill out the diary properly and one woman has violated the protocol taking the medication during mild headache. Of those who completed the study, 11 took rizatriptan plus rofecoxib, 4 rizatriptan plus tolfenamic acid, 3 zolmitriptan plus rofecoxib, 1 zolmitriptan plus tolfenamic acid and 1 patient took sumatriptan plus tolfenamic acid (Table 1). The 20 patients did take, as a third medication, a single tablet of $4 \mathrm{mg}$ of dexamethasone. All patients took oral formulations, none exceeded the twice-a-week limit and none presented vomiting after that. Before the study, the patients took the same triptans and NSAID used in this trial. Among all 20 patients, one female and one male patient presented recurrence in 3 out of the 6 attacks (50\%), while the 
Table 1. Drugs used in the study with dexamethasone (also used previously to the combination).

\begin{tabular}{lc}
\hline Acute treatment & No of patients \\
\hline Rizatriptan + rofecoxib & 11 \\
Rizatriptan + tolfenamic acid & 4 \\
Zolmitriptan + rofecoxib & 3 \\
Zolmitriptan + tolfenamic acid & 1 \\
Sumatriptan + tolfenamic acid & 1 \\
\hline
\end{tabular}

Table 2. Side effects reported.

\begin{tabular}{lc}
\hline Side effects & No of patients (percentage) * \\
\hline Heartburn & $6(30 \%)$ \\
Asthenia & $5(25 \%)$ \\
Somnolence & $3(15 \%)$ \\
\hline
\end{tabular}

* Eight patients (40\%) had three side effects and 4 patients (20\%) two side effects.

remaining 18 patients revealed recurrence in 1 or 2 out of the 6 attacks treated (mean $23,4 \%)(p<0,001)$. The side effects reported were heartburn ( 6 patients, $30 \%$ ), somnolence (5 patients, $25 \%$ ), and asthenia (3 patients, 15\%). Eight patients (40\%) presented the three side effects and 4 patients $(20 \%)$ two of the referred adverse events. None of the 12 patients that revealed side effects, considered it different from previous manifestations with the use of their usual acute treatment (Table 2).

\section{DISCUSSION}

Recurrence is a major problem with the use of all triptans, some more than others, even though it may happen with drugs taken for the acute treatment of migraine that are not selective agonists of serotonin receptors ${ }^{4,8}$. The definition of recurrence is the returning of the headache after 2 and before 24 hours, once the intensity of the pain firstly decreased from severe or moderate to mild or none. The time to recurrence after the different triptans is varied. Sumatriptan, for instance, may promote recurrence after 6-7 hours with the nasal spray, 10 hours with the injectable formulation and 17 hours with the tablet ${ }^{15-17}$. In one third of the patients treated with sumatriptan, recurrence may occur several times in the same attack (multiple recurrence) ${ }^{5}$. With regard to zolmitriptan, $32 \%$ of the attacks treated recur even though a second dose promotes relief in $90 \%$ of the patients after 2 hours $^{6}$. The underlying mechanisms of recurrence are still uncertain, but may be related to reversible receptor biding and/or short plasma half-life of the drug ${ }^{18,19}$. The combination of sumatriptan and tolfenamic acid or naproxen sodium decrease recurrence rate ${ }^{8,9}$ but some patients still present frequent recurrence, even switching triptans and NSAID. This fact therefore, may limit the utilization of such effective options for migraine treatment.

Steroids have been suggested for the acute treatment of migraine attacks as well as to interrupt status migranosus ${ }^{12,13,20}$. Dexamethasone given intravenously at a dose of $6 \mathrm{mg}$ following the administration of metoclopramide, was demonstrated to be effective in the treatment of a migraine attack ${ }^{20}$. The combination of dexamethasone and narcotics provide even further relief ${ }^{12}$ and a 2-day course of 40 $60 \mathrm{mg}$ of prednisone appears to shorten dramatically the duration of status migranosus ${ }^{21}$. The mechanisms by which steroids are useful in headache are uncertain but it is suggested that an anti-inflammatory effect on neurogenic inflammation, reduction of vasogenic oedema and effects on central aminergic / serotonergic systems may play a decisive role ${ }^{22}$. The toxicity of steroids is well known and may occur even with short-term use, especially in high-dose schemes, but the strict limitation of its dosage and use to a maximum of twice a week is generally well tolerated by healthy patients ${ }^{23}$.

This study deserves criticism since it was not blinded and also raises the issue of the possibility that the sole use of a triptan plus dexamethasone or a NSAID plus dexamethasone would have the same effect on the migraine attack and recurrence, therefore demanding controlled studies to justify the three-drug prescription regimen to be used. However, polytherapy for the acute treatment of migraine attacks have been used and suggested since the pathophysiological mechanisms of migraine seems to involve various underlying processes as inflammation, vasodilatation and dopaminergic hypersensitivity $^{24}$. The rational for the use of dexamethasone may be seen as the possible way to obtain a further anti-inflammatory effect since recurrence may occur due to the lack of a long lasting agonism on 5HT1D receptors providing reversal of neurogenic inflammation and/or inhibition of prostaglandin synthesis and release.

One might argue about the real advantage of prescribing a potentially harmful drug instead of providing longer action of a serotonin agonist or even increasing the dosage of the NSAID. Besides, the addition of a dopaminergic antagonist such as domperidone or metoclopramide, with their gastrocinetic 
activity ${ }^{24}$, may augment efficacy of a triptan or a NSAID simply by increasing gastrointestinal transit and absorption. This would provide a better effect ${ }^{25}$ and eliminate the necessity to use a steroid. Those arguments are valid but it has to be emphasized that these patients belong to a special and limited group that do not reduce recurrence even though taking such combination of substances.

We concluded that the addition of dexamethasone $4 \mathrm{mg}$ PO to a triptan plus a NSAID in a maximum rate of intake of twice a week, reduces recurrence and is well tolerated in those patients still presenting with frequent recurrence. Further and controlled studies are necessary to elucidate the real mechanisms of recurrence as well as to confirm the role of steroids as an intermittent and infrequent effective option for the acute treatment of migraine.

Acknowledgements - The authors wish to express their appreciation and gratitude to Dr. Carlos Alberto Bordini for the accomplishment of the statistical analysis.

\section{REFERENCES}

1. Peroutka SJ. Sumatriptan in acute migraine: pharmacology and review of world experience. Headache 1990;30(Suppl 2):554-560.

2. Wisser WH, Klein KB, Cox RC, Jones D, Ferrari MD. 311C90, a new central and peripherally acting 5-HT1D receptor agonist in the acute treatment of migraine: a double-blind, placebo-controlled, dose rangefinding study. Neurology 1996;46:522-526.

3. Cutler NR, Claghorn J, Sramek JJ, et al. Pilot study of MK-462 in migraine. Cephalalgia 1996;16:113-116.

4. Dalhof CG. How does sumatriptan perform in clinical practice? Cephalalgia 1995;15(Suppl 15):21-28

5. Ferrari MD, Visser WH. Sumatriptan in clinical practice: a 2-year review of its effects and limitations. In Olesen J, Tfelt-Hansen P (eds) Headache treatment: trial methodology and new drugs. Philadelphia: Lippincott-Raven 1997;30:181-188.

6. The International 311C 90 Long-term Study Group. The long-term tolerability and efficacy of oral zolmitriptan (Zomig 311C90) in the acute treat ment of migraine: an international study. Headache 1998;38:173-183.
7. Tfelt-Hansen P, McEwen J. Nonsteroidal antiinflammatory drugs in the acute treatment of migraine. In Olesen J, Tfelt-Hansen P, Welch KMA (eds). The headaches. 2.Ed. Philadelphia: Lippincott Williams \& Wilkins 2000:391-397.

8. Krymchantowski AV, Adriano M, Fernandes D. Tolfenamic acid decreases migraine recurrence when used with sumatriptan. Cephalalgia 1999;19:186-187.

9. Krymchantowski AV. Naproxen sodium decreases migraine recurrence when administered with sumatriptan. Arq Neuropsiquiatr 2000;58:428-430.

10. Silberstein SD, Schulman EA, Hopkins MM. Repetitive intravenous DHE in the treatment of refractory headache. Headache 1990;30:334-339.

11. Saper JR. Chronic opioid Rx for non-malignant pain? Top Pain Manage 1990;5:45.

12. Gallagher RM. Emergency treatment of intractable migraine. Headache 1986;26:74-75.

13. Levine BD, Yoshimura T, Kobayashi T, Fukushima M, Shibamoto T, Ueda G. Dexamethasone in the treatment of acute mountain sickness. N Eng J Med 1987;321;1707-1719.

14. Headache Classification Committee of the International Headache Society. Classification and diagnostic criteria for headache disorders, cranial neuralgias and facial pain. Cephalalgia 1988, 8(Suppl 7):1-96.

15. Tfeltf-Hansen P. Sumatriptan for the treatment of migraine attacks: a review of controlled clinical trials. Cephalalgia 1993;13:238-244.

16. Ferrari MD, James $\mathrm{MH}$, Bates D, et al. Oral sumatriptan: effect of a second dose, and incidence and treatment of headache recurrences. Cephalalgia 1994;14:330-338.

17. Visser WH, de Vriend RH, Jaspers MH, Ferrari MD. Sumatriptan in clinical practice: a 2-year review of 453 migraine patients. Neurology 1996;47:46-51.

18. Plosker GL, Mc Tavish D. Sumatriptan: a reappraisal of its pharmacology and therapeutic efficacy in the acute treatment of migraine and cluster. Drugs 1992;43:776.

19. Goadsby P, Silberstein SD. In Blue Books of Practical Neurology. Vol. 17. Headache. Boston:Butterworth-Heinemann 1997;8:123.

20. Klapper JA, Stanton JS. The emergency treatment of acute migraine headache; a comparison of intravenous dihydroergotamine, dexamethasone, and placebo. Cephalalgia 1991;11(Suppl 11):159-160.

21. Edmeads J. Management of the acute attack of migraine. Headache 1973;13:90-94

22. Saper JR, Silberstein SD, Gordon CD, Hamel RL. Handbook of headache management. Baltimore:Williams \& Wilkins, 1993:49.

23. Schimmer BP, Parker KL. Adrenocorticopropic hormone; adrenocortical steroids and their synthetic analogs; inhibitors of the synthesis and actions of adrenocortical hormones. In Goodman LS, Gilman A. (eds) The pharmacological basis of therapeutics. New York: McGraw-Hill, 1996:1459-1485

24. Peroutka SJ. Beyond monotherapy: rational politherapy in migraine. Headache 1998;38:18-22.

25. MacGregor EA, Wilkinson M, Bancroft K. Domperidone plus paracetamol in the treatment of migraine. Cephalalgia 1993;13:124-127. 